\title{
Pharmacovigilance knowledge in Brazil: perception of participants of oncology patient advocacy group on adverse events reporting
}

Conhecimento de farmacovigilância no Brasil: percepção de participantes de um grupo de advocacy de pacientes de oncologia sobre informes de eventos adversos

Guilherme Silva Julian', Renato Watanabe de Oliveira', Eimy Minowa', Luiza Cecilio², Luciana Holtz de Camargo Barros ${ }^{2}$

\begin{abstract}
Objective: Pharmacovigilance revolves around the maintenance and understanding of drug safety through detection and evaluation of spontaneous adverse events (AE) reporting. However, underreported phenomenon occurs often due inefficient spontaneous reporting by patients, physicians, healthcare professionals and caregivers. Therefore, the aim of this survey was to evaluate the knowledge and perception related to pharmacovigilance in Brazil. Methods: From February to March 2015, 260 respondents answered an internet-based survey related to knowledge on pharmacovigilance from Oncoguia Institute, an independent non-profit cancer patient advocacy group. Descriptive analyses were performed according to answers frequency. Results: Among the respondents, $40.7 \%$ were diagnosed with breast cancer, followed by hematological malignancies (6.5\%). Reported treatment included chemotherapy (35.9\%), surgery (28.7\%), and radiotherapy (16.4\%). Most of the respondents were not aware of the importance of a pharmacovigilance AE report (51.7\%). In fact, $21.3 \%$ of the respondents were not aware of what AEs are. In $65 \%$ of the cases, physicians have described the main AE expected to the prescribed treatment. Respondents reported nausea (23.6\%), hair loss (22.8\%), weight gain (14.5\%) and vomiting (13.2\%) as the most common AEs. Only $7.2 \%$ and $4.2 \%$ of the respondents were aware that AEs could be reported to pharmaceutical industry and ANVISA, respectively. Conclusions: This survey demonstrates that knowledge and perception regarding AEs and pharmacovigilance activities are very poor among overall population, including cancer patients. Therefore, there is an enormous demand for educational awareness of AEs reporting importance in overall population, patients, and physicians, especially in oncology.
\end{abstract}

Keywords: Health Surveys; Medical Oncology; Drug-Related Side Effects and Adverse Reactions; Pharmacovigilance

1. Evidências Kantar Health, Clinical Research Department - São Paulo - São Paulo - Brazil.

2. Instituto Oncoguia, Instituto Oncoguia - São Paulo - SP - Brazil.

Financial support: none to declare.

Conflicts of interest: The authors declare no conflict of interest relevant to this manuscript.

Correspondence author: Luciana Holtz de Camargo Barros. Alameda Lorena, 131, conjunto 116. CEP $01424-000$ - São Paulo-SP - Brazil.

E-mail: lucianaholtz@oncoguia.org.br. Phone/fax number: +55 1130536917 


\section{RESUMO}

Objetivo: A farmacovigilância gira em torno da manutenção e compreensão da segurança de medicamentos por meio da detecção e avaliação de relatos de eventos adversos espontâneos (EA). No entanto, o fenômeno da subnotificação ocorre frequentemente devido à notificação espontânea ineficiente por parte de pacientes, médicos, profissionais de saúde e cuidadores. Portanto, o objetivo desta pesquisa foi avaliar o conhecimento e a percepção relacionada à farmacovigilância no Brasil. Métodos: De fevereiro a março de 2015, 260 entrevistados responderam a uma pesquisa na Internet relacionada ao conhecimento sobre farmacovigilância do Oncoguia Institute, um grupo independente de defesa de pacientes com câncer sem fins lucrativos. Análises descritivas foram realizadas de acordo com a frequência de respostas. Resultados: Entre os entrevistados, 40,7\% foram diagnosticados com câncer de mama, seguidos por neoplasias hematológicas (6,5\%). 0 tratamento relatado incluiu quimioterapia (35,9\%), cirurgia (28,7\%), radioterapia $(16,4 \%)$. A maioria dos entrevistados não estava ciente da importância de um relatório de EA farmacovigilância $(51,7 \%)$. De fato, $21,3 \%$ dos entrevistados não sabiam o que são os EAs. Em 65\% dos casos, os médicos descreveram o principal EA esperado para o tratamento prescrito. Os entrevistados relataram náuseas (23,6\%), perda de cabelo $(22,8 \%)$, ganho de peso $(14,5 \%)$ e vômitos $(13,2 \%)$ como EAs mais comuns. Apenas $7,2 \%$ e 4,2\% dos entrevistados sabiam que os EAs poderiam ser comunicados à indústria farmacêutica e à ANVISA, respectivamente. Conclusões: Esta pesquisa demonstra que o conhecimento e a percepção sobre os EAs e atividades de farmacovigilância são muito pobres na população geral, incluindo pacientes com câncer. Portanto, há uma enorme demanda por conscientização educacional dos EAs que relatam importância na população geral, pacientes e médicos, especialmente em oncologia.

Descritores: Pesquisas de Saúde; Oncologia Médica; Efeitos colaterais relacionados às drogas e reações adversas; Farmacovigilância

\section{INTRODUCTION}

Cancer is one the major causes of mortality worldwide, being responsible for 8.2 million deaths in 2012. ${ }^{(1,2)}$ In addition, the malignant characteristic of cancer is not only responsible for the high mortality rates, but also have a huge impact on morbidity, including patient's quality of life, affecting their psychological and socioeconomic status during the disease management. ${ }^{(3)}$

Oncology patients' associations play an important role in attenuating some of these burdens. These associations provide information about the disease and its management to patients, and support patients to share their experiences, as well as provide emotional support.(4-6) In oncology, patient's association may also aim to promote prevention, early detection, quality-of-life, and legal rights. Among the patients' associations in Brazil, Oncoguia is a patient advocacy group that supports and guide patients to manage the disease, minimizing the barriers though awareness about the disease, treatment, among others. ${ }^{(7)}$ Its mission statement is to help cancer patients to live better.
The occurrence of adverse events (AE) are one the main barriers for disease management faced by patients during cancer treatment. AEs are very frequent in oncology treatments, and usually underreported, due to different barriers, including not enough and inefficient spontaneous reporting by patient. ${ }^{(8)}$ Defined by WHO as the science to detect, assess, understand, and prevent of adverse effects, ${ }^{(9)}$ pharmacovigilance (PV) is a key area to reduce adverse events and ensure the patient safety. To be effective, PV have to be supplied by reports of AEs, especially spontaneous reports from different sources, including patients. ${ }^{(10)}$

In fact, AE reports from patients usually have a detailed description of AE's impact, including the severity and influence in daily life. ${ }^{(11)}$ However, there are also evidences showing lack of awareness from healthcare professionals (HCPs) and patients regarding PV and its role in drug safety evaluation. ${ }^{(12-15)}$ In Brazil, to our knowledge, there are no evidences showing the level of awareness and reporting of adverse events by patients. The present study aims to describe the level of knowledge of patients about PV and $\mathrm{AES}$ and to identify barriers on AE reporting. 


\section{METHODS}

The primary objective of this internet-based survey was to collect data from Oncoguia website users' knowledge about PV and AEs reporting. Therefore, we developed a questionnaire and made it available for participation in Oncoguia Institute's website, from April 2012 until October 2014. The study population eligible to participate in the study consisted of all Oncoguia's users with internet access that have followed the institute webpage (more than 14 million accesses in 2017) or Facebook page (more than 215,000 followers). The study included all patients, no exclusion criteria was considered.

All the participants were asked to give their consent to participate in the study. According to the Brazilian regulation (resolution 510/2016), anonymized surveys of personal opinion do not require the approval from ethics committee. ${ }^{(16)}$ No personal data and identifiers was collected; therefore, all the data was fully anonymized to ensure participants confidentiality, integrity, and privacy.

\section{Questionnaire}

We developed the questionnaire in an online platform, consisting of 23 multiple-choice and one open-ended questions. After its development, an internal expert team validated the questionnaire and published it in Oncoguia institute's website. All site users who were interested in participating in the survey provided an informed consent.
To describe the knowledge on PV and AEs reporting, the questionnaire was developed in Portuguese and it was divided in sections:

- Participants demographics, such as age, Brazilian state of residence, educational level, and healthcare plan;

- Clinical information, consisting of the type of cancer and treatment information;

- Knowledge about PV and AEs: definition of AE, the information provided by the HCP about AEs, $A E s$ experienced by the patient, the knowledge on reporting $A E$, the definition of $P V$, the importance of reporting AEs; and an open-ended question for patients' opinion on this subject.

\section{Data analysis}

Survey responses were extracted, with counting/ ranking for those related to multiple-choice and categorization for those related to open questions. Subsequently, frequency analyses of all responses were performed to summarize results, with descriptive purposes only. All results are reported as rate of respondents with multiple choices for several questions.to achieve. The primary objective of this study was to describe knowledge and awareness in AE among oncology patients, therefore, this was a descriptive study with no formal hypothesis tested.

\section{RESULTS}

\section{Participants' demographics}

A total of 263 participants responded the questionnaire, of which most were 35-50 years old (38.8\%). Most participants were from south and southeast geographic regions (19.0 and $56.7 \%$, respectively). Regarding the educational level, most participants have completed the high school (25.1\%), followed by complete faculty (22.8\%) and post-graduate (14.1\%). A balanced distribution was observed regarding type of healthcare system: $44.9 \%$ were from public healthcare system and $41.8 \%$ were from private healthcare insurance. Table 1 shows the demographics characteristics of patients.

\section{Clinical characteristics}

According to the results obtained, patients from different cancer types responded the questionnaire, of which breast cancer was the most prevalent (40.7\%), followed by hematological malignancies (6.5\%) and ovarian cancer (3.8\%). The most commonly reported treatment strategies were chemotherapy (35.9\%), surgery (28.7\%) and radiotherapy (16.4\%), while the most common treatment regimens were surgery + chemotherapy (22.4\%) and surgery + chemotherapy + radiotherapy (17.1\%) (Table 2 ).

\section{Adverse events}

Only approximately half of the included participants claimed to know what is an adverse event (54.8\%) and most of them mentioned that their physician talked about the possible adverse events of their treatments (65\%). In addition, according to participants, more than half of them reported that the HCPs team also mentioned the possible adverse events (57.0\%), not only their physicians (Table 3).

Many of the participants (66.5\%) mentioned talking to their physicians about the $A E$, of which the clear majority reported during the appointment (92\%). Some participants answered not reporting their AEs to the physician because they did not consider it important (42.1\%), or have forgotten to mention (15.8\%). Most of the participants reported taking other medications to control the AEs (48.3\%). Moreover, $46 \%$ of participants reported experiencing some $A E$ that was not mentioned by the HCPs team or their physician. Most patients reported these AEs during the appointment with their physicians (75.2\%) (Table 3).

Regarding the AEs, the participants described nausea as the most common AE (23.6\%), followed by hair loss (22.8\%) and weight gain (14.5\%). In addition, almost $70 \%$ of the participants experienced at least one AE (Table 4). 
Table 1. The demographic characteristics of the patients

\begin{tabular}{|c|c|c|}
\hline \multirow{2}{*}{ Characteristic } & \multicolumn{2}{|c|}{ Total $(\mathrm{N}=263)$} \\
\hline & $\mathrm{N}$ & $\%$ \\
\hline \multicolumn{3}{|l|}{ Age } \\
\hline$<20$ years & 5 & $1.9 \%$ \\
\hline $21-35$ years & 57 & $21.7 \%$ \\
\hline $36-50$ & 102 & $38.8 \%$ \\
\hline$>50$ years & 94 & $35.7 \%$ \\
\hline Not reported & 5 & $1.9 \%$ \\
\hline \multicolumn{3}{|l|}{ Geographic region } \\
\hline South & 50 & $19.0 \%$ \\
\hline Southeast & 149 & $56.7 \%$ \\
\hline Midwest & 11 & $4.2 \%$ \\
\hline Northeast & 33 & $12.5 \%$ \\
\hline North & 10 & $3.8 \%$ \\
\hline Not reported & 10 & $3.8 \%$ \\
\hline \multicolumn{3}{|l|}{ Educational level } \\
\hline Elementary/middle school & 24 & $9.1 \%$ \\
\hline Incomplete high school & 29 & $11.0 \%$ \\
\hline Complete high school & 66 & $25.1 \%$ \\
\hline Incomplete university degree & 35 & $13.3 \%$ \\
\hline Complete university & 60 & $22.8 \%$ \\
\hline Post-graduate & 37 & $14.1 \%$ \\
\hline No education & 4 & $1.5 \%$ \\
\hline Not reported & 8 & $3.0 \%$ \\
\hline \multicolumn{3}{|l|}{ Type of healthcare plan } \\
\hline SUS & 118 & $44.9 \%$ \\
\hline Private health insurance & 110 & $41.8 \%$ \\
\hline SUS + Private health insurance & 21 & $8.0 \%$ \\
\hline Private health insurance + Out-of-pocket & 1 & $0.4 \%$ \\
\hline Out-of-pocket & 6 & $2.3 \%$ \\
\hline Not reported & 5 & $1.9 \%$ \\
\hline Other & 2 & $0.8 \%$ \\
\hline
\end{tabular}

* SUS - Sistema Único de Saúde, Unified Healthcare System (Public)

\section{Pharmacovigilance awareness}

According to respondents, $62.7 \%$ reported not knowing that patients could report AEs to the manufacturer, and $67.3 \%$ did not know that either physician or themselves could report AEs to ANVISA (Agência Nacional de vigilância Sanitária [Brazilian Health Surveillance Agency]) and manufacturer. In the occurrence of an $A E$, not even half of the patients answered reporting it to their physician (49.4\%), only $1.1 \%$ reported to the manufacturer. Approximately $65 \%$ of the participants never heard about PV and $51.7 \%$ did not know the importance of reporting AEs (Table 5).

Table 6 describes some patients' testimonials regarding pharmacovigilance awareness and perceptions. The testimonials selected represent the thoughts most commonly reported by patients in the survey. 
Table 2. The clinical and treatment characteristics of the patients

\begin{tabular}{|c|c|c|}
\hline \multirow{2}{*}{ Characteristic } & \multicolumn{2}{|c|}{ Total $(\mathrm{N}=263)$} \\
\hline & $\mathrm{N}$ & $\%$ \\
\hline \multicolumn{3}{|l|}{ Type of cancer } \\
\hline Breast cancer & 107 & $40.7 \%$ \\
\hline Hematological Malignancies & 17 & $6.5 \%$ \\
\hline Ovary cancer & 10 & $3.8 \%$ \\
\hline Colorectal cancer & 8 & $3.0 \%$ \\
\hline Stomach cancer & 6 & $2.3 \%$ \\
\hline Non-Small Cell Lung Cancer & 6 & $2.3 \%$ \\
\hline Other & 36 & $13.7 \%$ \\
\hline Not reported & 73 & $27.8 \%$ \\
\hline \multicolumn{3}{|l|}{ Type of treatment } \\
\hline Chemotherapy & 195 & $35.9 \%$ \\
\hline Surgery & 156 & $28.7 \%$ \\
\hline Radiotherapy & 89 & $16.4 \%$ \\
\hline Hormone Therapy & 39 & $7.2 \%$ \\
\hline Others & 2 & $0.4 \%$ \\
\hline Not reported & 62 & $11.4 \%$ \\
\hline \multicolumn{3}{|l|}{ Therapy regimens } \\
\hline Surgery + Chemotherapy & 59 & $22.4 \%$ \\
\hline Surgery + Chemotherapy + Radiotherapy & 45 & $17.1 \%$ \\
\hline Chemotherapy & 32 & $12.2 \%$ \\
\hline Surgery + Chemotherapy + Radiotherapy + Hormone Therapy & 30 & $11.4 \%$ \\
\hline Surgery & 13 & $4.9 \%$ \\
\hline Chemotherapy + Radiotherapy & 8 & $3.0 \%$ \\
\hline Surgery + Radiotherapy & 4 & $1.5 \%$ \\
\hline Surgery + Chemotherapy + Hormone Therapy & 3 & $1.1 \%$ \\
\hline Hormone Therapy & 2 & $0.8 \%$ \\
\hline Chemotherapy + Radiotherapy + Hormone Therapy & 2 & $0.8 \%$ \\
\hline Surgery + Hormone Therapy & 2 & $0.8 \%$ \\
\hline Other & 1 & $0.4 \%$ \\
\hline Not reported & 62 & $23.6 \%$ \\
\hline
\end{tabular}


Table 3. The knowledge and behavior of participants over adverse events

\begin{tabular}{|c|c|c|}
\hline \multirow{2}{*}{ Question } & \multicolumn{2}{|c|}{ Total $(\mathrm{N}=263)$} \\
\hline & $\mathrm{N}$ & $\%$ \\
\hline \multicolumn{3}{|l|}{ Do you know what an $A E$ is? } \\
\hline Yes & 144 & $54.8 \%$ \\
\hline No & 56 & $21.3 \%$ \\
\hline Not reported & 63 & $24.0 \%$ \\
\hline \multicolumn{3}{|l|}{ Did your physician talk about the expected AEs of your treatment? } \\
\hline Yes & 171 & $65.0 \%$ \\
\hline No & 29 & $11.0 \%$ \\
\hline Not reported & 63 & $24.0 \%$ \\
\hline \multicolumn{3}{|l|}{ Did the medical team talk about the expected AE of your treatment? } \\
\hline Yes & 150 & $57.0 \%$ \\
\hline \multicolumn{3}{|l|}{ Specify the healthcare professional: } \\
\hline Nurse & 134 & $89.3 \%$ \\
\hline Pharmacist & 12 & $8.0 \%$ \\
\hline Psychologist & 6 & $4.0 \%$ \\
\hline Nutritionist & 4 & $2.7 \%$ \\
\hline Social worker & 2 & $1.3 \%$ \\
\hline Not reported & 3 & $2.0 \%$ \\
\hline No & 48 & 18.3 \\
\hline Not reported & 65 & $24.7 \%$ \\
\hline \multicolumn{3}{|l|}{ Did you experience an AE that your physician mentioned about your treatment? } \\
\hline Yes & 184 & $70.0 \%$ \\
\hline No & 13 & $4.9 \%$ \\
\hline Not reported & 66 & $25.1 \%$ \\
\hline \multicolumn{3}{|l|}{ Did you talk to your physician about the experienced $A E ?$} \\
\hline Yes & 175 & $66.5 \%$ \\
\hline \multicolumn{3}{|l|}{ If yes, how did you talk to your physician? } \\
\hline During the consultation & 161 & $92.0 \%$ \\
\hline By email & 1 & $0.6 \%$ \\
\hline By phone & 10 & $5.7 \%$ \\
\hline Not reported & 4 & $2.3 \%$ \\
\hline No & 19 & $7.2 \%$ \\
\hline \multicolumn{3}{|l|}{ If no, why did you not talk? } \\
\hline I did not report because I did not know it was important & 8 & $42.1 \%$ \\
\hline I did not report because I forgot & 3 & $15.8 \%$ \\
\hline Other & 5 & $26.3 \%$ \\
\hline Not reported & 3 & $15.8 \%$ \\
\hline Not reported & 69 & $26.2 \%$ \\
\hline \multicolumn{3}{|l|}{ In case you experienced an $A E$, was any action taken because of it? Please, specify. } \\
\hline I started taking medications to manage the AEs & 127 & $48.3 \%$ \\
\hline My treatment has changed (e.g.: changed to another chemotherapy) & 11 & $4.2 \%$ \\
\hline The dose of my chemotherapy was changed & 7 & $2.7 \%$ \\
\hline Other & 7 & $2.7 \%$ \\
\hline Not reported & 111 & $42.2 \%$ \\
\hline \multicolumn{3}{|l|}{ Did you experience an AE that your physician did not mention? } \\
\hline Yes & 121 & $46.0 \%$ \\
\hline \multicolumn{3}{|l|}{ If yes, how did you report it? } \\
\hline During the consultation & 91 & $75.2 \%$ \\
\hline By email & 23 & $19.0 \%$ \\
\hline By phone & 7 & $5.8 \%$ \\
\hline Not reported & 78 & $29.7 \%$ \\
\hline
\end{tabular}


Table 4. The most common adverse events reported by the patients

\begin{tabular}{|c|c|c|}
\hline Characteristic & N & $\%$ \\
\hline \multicolumn{3}{|c|}{ Frequency of the most experienced AEs (total $=622$ ) } \\
\hline Nausea & 147 & $23.6 \%$ \\
\hline Hair loss & 142 & $22.8 \%$ \\
\hline Weight gain & 90 & $14.5 \%$ \\
\hline Vomiting & 82 & $13.2 \%$ \\
\hline Anemia & 50 & $8.0 \%$ \\
\hline Weight loss & 50 & $8.0 \%$ \\
\hline Neuropathy & 26 & $4.2 \%$ \\
\hline Others & 35 & $5.6 \%$ \\
\hline \multicolumn{3}{|c|}{ Proportion of patients who experienced each AE (total $=184$ ) } \\
\hline Nausea & 147 & $79.9 \%$ \\
\hline Hair loss & 142 & $77.2 \%$ \\
\hline Weight gain & 90 & $48.9 \%$ \\
\hline Vomiting & 82 & $44.6 \%$ \\
\hline Anemia & 50 & $27.2 \%$ \\
\hline Weight loss & 50 & $27.2 \%$ \\
\hline Neuropathy & 26 & $14.1 \%$ \\
\hline Others & 35 & $19.0 \%$ \\
\hline \multicolumn{3}{|c|}{ Distribution of patients according to the number of experienced AEs } \\
\hline $0 \mathrm{AES}$ & 81 & $30.8 \%$ \\
\hline 1 & 15 & $5.7 \%$ \\
\hline 2 & 35 & $13.3 \%$ \\
\hline 3 & 41 & $15.6 \%$ \\
\hline 4 & 47 & $17.9 \%$ \\
\hline 5 & 22 & $8.4 \%$ \\
\hline 6 & 13 & $4.9 \%$ \\
\hline 7 & 8 & $3.0 \%$ \\
\hline 8 & - & $-\%$ \\
\hline 9 & 1 & $0.4 \%$ \\
\hline
\end{tabular}


Table 5. The pharmacovigilance awareness among the participants

\begin{tabular}{|c|c|c|}
\hline \multirow{2}{*}{ Question } & \multicolumn{2}{|c|}{ Total (N=263) } \\
\hline & N & $\%$ \\
\hline \multicolumn{3}{|c|}{$\begin{array}{l}\text { Did you know that AEs (expected or unexpected) could be reported to } \\
\text { the manufacturer? }\end{array}$} \\
\hline Yes & 19 & $7.2 \%$ \\
\hline No & 165 & $62.7 \%$ \\
\hline Not reported & 79 & $30.0 \%$ \\
\hline \multicolumn{3}{|c|}{$\begin{array}{l}\text { Did you know that you or your physician should report AEs to ANVISA } \\
\text { and to manufacturer? }\end{array}$} \\
\hline Yes & 11 & $4.2 \%$ \\
\hline No & 177 & $67.3 \%$ \\
\hline Not reported & 75 & $28.5 \%$ \\
\hline \multicolumn{3}{|l|}{ In the occurrence of an $A E$, you: } \\
\hline Reported to your physician and/or medical team & 130 & $49.4 \%$ \\
\hline Did not reported & 41 & $15.6 \%$ \\
\hline Reported to the manufacturer & 3 & $1.1 \%$ \\
\hline Other & 1 & $0.4 \%$ \\
\hline Not reported & 88 & $33.5 \%$ \\
\hline \multicolumn{3}{|l|}{ Do you know what pharmacovigilance is? } \\
\hline Yes & 24 & $9.1 \%$ \\
\hline No & 170 & $64.6 \%$ \\
\hline Not reported & 69 & $26.2 \%$ \\
\hline \multicolumn{3}{|l|}{ Do you know why it is important to report the AEs? } \\
\hline Yes & 55 & $20.9 \%$ \\
\hline No & 136 & $51.7 \%$ \\
\hline Not reported & 72 & $27.4 \%$ \\
\hline
\end{tabular}

Table 6. Patients' quotes about their experience

\begin{tabular}{|c|c|c|c|}
\hline Patient age & Healthcare system & $\begin{array}{c}\text { Educational } \\
\text { level }\end{array}$ & Patient testimonial in the end of the questionnaire \\
\hline $36-50$ & SUS & $\begin{array}{l}\text { Complete } \\
\text { university }\end{array}$ & $\begin{array}{l}\text { "...Unfortunately, in Brazil, anyone who is submitted to a cancer } \\
\text { treatment is (not) informed correctly, not even heard. HCPs only } \\
\text { care about providing the main treatment, such as surgery, radio- } \\
\text { therapy, chemotherapy and, after that, the patient is left with the } \\
\text { adverse effects..." }\end{array}$ \\
\hline$>51$ & SUS & $\begin{array}{l}\text { Complete } \\
\text { university }\end{array}$ & $\begin{array}{l}\text { "I know it's important to report side effects, I pass them on to the } \\
\text { doctor and I think they report to the manufacturer. But (commu- } \\
\text { nication between) patient/manufacturer, I do not know how (to } \\
\text { report) or if I would be listened to (or) taken seriously." }\end{array}$ \\
\hline$>51$ & $\begin{array}{c}\text { SUS + private } \\
\text { health insurance }\end{array}$ & $\begin{array}{c}\text { Complete } \\
\text { high school }\end{array}$ & $\begin{array}{l}\text { "I think patients should be informed about indications and con- } \\
\text { traindications before treatment begins, because I, unfortunately, } \\
\text { had many doubts during the treatment, which were clarified only } \\
\text { after they have appeared. I think that those who have cancer, } \\
\text { have to be very well informed, otherwise we end up going crazy." }\end{array}$ \\
\hline
\end{tabular}




\section{DISCUSSION}

The study described the level of knowledge over pharmacovigilance and $A E$ reporting among users from Oncoguia website. In general, our findings show a high number of AEs, a poor familiarity with drug safety and a reporting activity directed to the physician. As expected in an oncologic population, most participants ( 75\%) were above 36 years old, with the majority of the participants from the southeast region, which is the most populous region in Brazil - accounting approximately $56.2 \%$ of total population. ${ }^{(17)}$ One of the important aspects of the sample is that, despite most participants having completed, at least, the high school, an expressive part has only elementary and incomplete high school (around 20\%) among adults (above 20 years-old).

In addition, our survey showed that breast cancer was the most common cancer among the participants, the most prevalent type of cancer in the world, with 1.67 million new cases diagnosed in 2012. ${ }^{(2)}$ In Brazil, breast cancer is the most common cancer (excluding non-melanoma skin cancer) among women, with more than 57,000 cases annually. ${ }^{(18)}$ The high number of breast cancer cases found in our study may be related to the important participation of breast cancer patients in Oncoguia orientations. (4,19) $^{-1}$

In the literature, it is well established that cancer-related treatments are related to a high number of AEs, including the hair loss for cancer patients. The study showed that approximately $70 \%$ of the participants presented at least one AE during their treatment. This is an important issue as AEs could reduce the patients' quality of life and adherence to treatment, especially for chronic diseases. In oncologic therapies, adverse events have a high impact in patients' adherence to treatment, which also affects the outcomes. ${ }^{(20)}$

AEs are responsible for almost $16 \%$ of inpatient hospitalizations and can lead a total cost of USD 6,235 per patient, in three-month period, in Sweden.(21) Besides, according to our findings, the most common strategy to manage AEs is the use of supportive drugs, increasing even more the economic impact and potentially reducing patients' quality of life.

Around $55 \%$ of the participants reported to know what an AE is; if we consider only the respondents, this proportion reaches $72 \%$. However, a different scenario was found in other studies. In Saudi Arabia, only 25\% of the respondents knew the correct definition of AEs, although they used a different questionnaire format and target population - this study was conducted with population from two malls in the city of Riyadh. ${ }^{(15)}$ The proportion found in our study is higher probably due to the increased awareness of AEs occurrence in oncologic patients, (22) and profile of visitors in patient advocacy group website, which may be more likely to proactively search information. ${ }^{(23)}$
Most participants mentioned that their physician or the HCPs informed about the expected AEs related to treatment. Considering that most participants experienced those expected AEs, it evidences the importance of the communication between HCP and patient about AEs (24). However, even with HCPs providing information to most of the patients, $46 \%$ of them reported experiencing AEs that were not mentioned by any HCP. Confidently, not all AEs are expected and patients may not remember of all AEs mentioned by their physicians. Nevertheless, a good patient-HCP communication plays an essential role in patients' treatment and QoL, as previously demonstrated.(25-27) For instance, a meta-analysis demonstrated a positive correlation between patient-HCP communication and adherence to treatment, and that the training of physicians' communication skills also enhances patients' adherence. ${ }^{(27)}$ Therefore, it is important to have a good patient-HCP communication, especially regarding the possible AEs related to treatment, in this case.

According to participants, the main method to report the adverse events is during the appointment with their physician. Indeed, most patients who experienced AEs reported them to their HCPs. ${ }^{(28)}$ This behavior is expected, as the patients believe their HCPs will be responsible for reporting the $A E s,{ }^{(29)}$ making the physicians the main channel for adverse events reporting. However, HCP-centered reporting could be an issue, as HCPs may not be properly familiarized with PV and drug safety, with a poor rate of AEs reporting, (12,30-32) including in Brazil. ${ }^{(8,33)}$

Our study demonstrated that most of survey respondents were not aware that patients and HCPs are allowed to report AEs to manufacturers and government health agency (ANVISA). In addition, most participants did not know the meaning of PV and the importance to report AEs. Our data along with the belief that HCPs are the responsible to report AEs are an indicative of $A E$ under-reporting in Brazil by patients. This finding is in agreement with the literature. ${ }^{\left({ }^{8}\right)}$ However, under-reporting AEs by patients is not limited to the Brazilian scenario, as even developed countries still present decreased awareness on AE reporting. ${ }^{(34)}$ However, it may be aggravated in our scenario due to lack of public policies/campaigns to minimize these barriers for $\mathrm{AE}$ reporting. Also, $\mathrm{AE}$ reports from patients are important to help add information provided by the HCPs, as they are usually described more detailed and from a subjective perspective of the patient. ${ }^{(11)}$

In addition, during the survey, a significant percentage of patients believed that reporting the AEs was not important or relevant. However, after the survey completion, most of them reported being interested in this subject and that more information should be provided to them, as described in Table 6. 
This study has several limitations. Data from this study are self-reported and cross-sectional in nature. Thus, there is no way to independently verify variables reported (e.g., diagnosis, medications taken) via other data sources. There is the potential for respondents to misreport some information due to recall bias. However, the survey is a relatively benign, low-risk situation with little incentive to misreport information. Also, given the cross-sectional nature of these survey data, statements of causality cannot be made from the study results.

\section{CONCLUSIONS}

In summary, the study provided important information regarding patients' PV and AEs reporting awareness in oncology patients in Brazil. According to our findings, most participants experienced AEs during oncologic treatment, evidencing the important burden of AEs. Moreover, despite most AEs risks have been informed by their physician/HCP, a high number of AEs were not mentioned during the appointment, showing a possible lack of patient-HCP communication and the importance of patients' support groups. The study also showed an AE-reporting centered in the HCPs and a lack of awareness of PV and $A E$ reporting importance. To improve the under-reporting scenario, educational measures should be performed to increase the awareness of AE reporting by the patients and HCPs.

\section{REFERENCES}

1. Ferlay J, Soerjomataram I, Dikshit R, Eser S, Mathers C, Rebelo M, et al. Cancer incidence and mortality worldwide: sources, methods and major patterns in GLOBOCAN 2012. Int J Cancer. 2015;136(5):E359-86.

2. Torre LA, Siegel RL, Ward EM, Jemal A. Global Cancer Incidence and Mortality Rates and Trends--An Update. Cancer Epidemiol Biomarkers Prev. 2016;25(1):16-27.

3. Singer S. Psychosocial Impact of Cancer. Recent Results Cancer Res. 2018;210:1-11.

4. van Eenbergen MC, van de Poll-Franse LV, Heine P, Mols F. The Impact of Participation in Online Cancer Communities on Patient Reported Outcomes: Systematic Review. JMIR Cancer. 2017;3(2):e15.

5. Huber J, Muck T, Maatz P, Keck B, Enders P, Maatouk I, et al. Face-to-face vs. online peer support groups for prostate cancer: A cross-sectional comparison study. J Cancer Surviv. 2018;12(1):19.

6. Kinnane NA, Milne DJ. The role of the Internet in supporting and informing carers of people with cancer: a literature review. Support Care Cancer. 2010;18(9):1123-36.

7. Instituto Oncoguia [Internet]. 2017 [cited 2017 Dec 19]. Available from: http://www.oncoguia. org.br/
8. Visacri MB, de Souza CM, Pimentel R, Barbosa CR, Sato CMS, Granja S, et al. Pharmacovigilance in oncology: pattern of spontaneous notifications, incidence of adverse drug reactions and under-reporting. Braz J Pharm Sci. 2014;50(2):41122.

9. World Health Organization. The Importance of Pharmacovigilance - Safety Monitoring of Medicinal Products. Geneva: World Health Organization; 2002. $52 \mathrm{p}$.

10. Stricker BH, Psaty BM. Detection, verification, and quantification of adverse drug reactions. BMJ. 2004;329(7456):44-7.

11. Inacio $P$, Cavaco $A$, Airaksinen $M$. The value of patient reporting to the pharmacovigilance system: a systematic review. Br J Clin Pharmacol. 2017;83(2):227-46.

12. Almandil NB. Healthcare professionals' awareness and knowledge of adverse drug reactions and pharmacovigilance. Saudi Med J. 2016;37(12):1359-64.

13. Shamim S, Sharib SM, Malhi SM, Muntaha SU, Raza $\mathrm{H}$, Ata $\mathrm{S}$, et al. Adverse drug reactions (ADRS) reporting: awareness and reasons of under-reporting among health care professionals, a challenge for pharmacists. Springerplus. 2016;5(1):1778.

14. Olsen AK, Whalen MD. Public perceptions of the pharmaceutical industry and drug safety: implications for the pharmacovigilance professional and the culture of safety. Drug Saf. 2009;32(10):805-10.

15. Sales I, Aljadhey H, Albogami Y, Mahmoud MA. Public awareness and perception toward Adverse Drug Reactions reporting in Riyadh, Saudi Arabia. Saudi Pharm J. 2017;25(6):868-72.

16. Brasil. Ministério da Saúde. Conselho Nacional de Saúde. Resolução No 510, de 07 de Abril de 2016. Brasília: Conselho Nacional de Saúde; 2016.

17. Brasil. Ministério do Planejamento, Desenvolvimento e Gestão. Instituto Brasileiro de Geografia e Estatística. Estimativas da População Residente no Brasil e Unidades da Federação com Data de Referência em $1^{\circ}$ de Julho de 2017. Brasília: Diário Oficial da União; 2017. 
18. Brasil. Ministério da Saúde. Instituto Nacional do Câncer. Estimativa 2016 - Incidência de Câncer no Brasil. Rio de Janeiro: INCA; 2016.

19. Holtz L, Minowa E, Julian G. Patients' Groups And Advocacy In Oncology: Awareness, Support And Unmet Needs. Value Health. 2015;18(3):A212.

20. Shingler SL, Bennett BM, Cramer JA, Towse A, Twelves C, Lloyd AJ. Treatment preference, adherence and outcomes in patients with cancer: literature review and development of a theoretical model. Curr Med Res Opin. 2014;30(11):232941.

21. Gyllensten H, Hakkarainen KM, Hägg S, Carlsten A, Petzold M, Rehnberg C, et al. Economic impact of adverse drug events--a retrospective population-based cohort study of 4970 adults. PLoS One. 2014;9(3):e92061.

22. Huynh TK, Trovato JA. Assessment of Patients' Knowledge and Management of Chemotherapy Related Adverse Effects. J Hematol Oncol Pharm. 2014;4(4):122-7.

23. Price $M$, Butow $P$, Kirsten L. Support and training needs of cancer support group leaders: a review. Psychooncology. 2006;15(8):651-63.

24. Baile WF, Aaron J. Patient-physician communication in oncology: past, present, and future. Curr Opin Oncol. 2005;17(4):331-5.

25. Song L, Bensen JT, Zimmer C, Sleath B, Blackard $B$, Fontham $E$, et al. Patient-health care provider communication among patients with newly diagnosed prostate cancer: findings from a population-based survey. Patient Educ Couns. 2013;91(1):79-84.

26. Song L, Hamilton JB, Moore AD. Patient-healthcare provider communication: perspectives of African American cancer patients. Health Psychol. 2012;31(5):539-47.
27. Zolnierek KB, Dimatteo MR. Physician communication and patient adherence to treatment: a meta-analysis. Med Care. 2009;47(8):826-34.

28. Sabblah GT, Darko DM, Mogtari H, Harmark L, van Puijenbroek E. Patients' Perspectives on Adverse Drug Reaction Reporting in a Developing Country: A Case Study from Ghana. Drug Saf. 2017;40(10):911-21.

29. Staniszewska A, Dabrowska-Bender M, Olejniczak D, Duda-Zalewska A, Bujalska- Zadrożny M. Patient knowledge on reporting adverse drug reactions in Poland. Patient Prefer Adherence. 2017;11:47-53.

30. Suyagh M, Farah D, Abu Farha R. Pharmacist's knowledge, practice and attitudes toward pharmacovigilance and adverse drug reactions reporting process. Saudi Pharm J. 2015;23(2):147-53.

31. Abdel-Latif MM, Abdel-Wahab BA. Knowledge and awareness of adverse drug reactions and pharmacovigilance practices among healthcare professionals in Al-Madinah Al-Munawwarah, Kingdom of Saudi Arabia. Saudi Pharm J. 2015;23(2):154-61.

32. Alsaleh FM, Alzaid SW, Abahussain EA, Bayoud T, Lemay J. Knowledge, attitude and practices of pharmacovigilance and adverse drug reaction reporting among pharmacists working in secondary and tertiary governmental hospitals in Kuwait. Saudi Pharm J. 2017;25(6):830-7.

33. Siman AG, Cunha SGS, Brito MJM. The practice of reporting adverse events in a teaching hospital. Rev Esc Enferm USP. 2017;51:e03243.

34. Avery A, Anderson C, Bond CM, Fortnum H, Gifford A, Hannaford PC, et al. Evaluation of patient reporting of adverse drug reactions to the UK Yellow Card Scheme': literature review, descriptive and qualitative analyses, and questionnaire surveys. Health Technol Assess. 2011;15(20):1-234, iii-iv. 